\title{
Sero-Prevalence of Herpes Virus Infection in Sudanese Pregnant Women
}

\author{
Eisa Osman El-Amin ${ }^{1 *}$, Osman Eisa Elamin², Rawia Abdul-Monim Ahmed ${ }^{3}$, Abdulrahman Khalid Abdulla ${ }^{4}$, Sara Eisa Elamin ${ }^{5}$ and Harun \\ Ibrahim Elhaj ${ }^{6}$
}

${ }^{1}$ Senior consultant, Department of Paediatrics, The National Ribat University hospital, PO box 55, Burri, Khartoum, Sudan

${ }^{2}$ Medical officer, Department of Paediatrics, The National Ribat University Hospital, PO box 55, Burri, Khartoum, Sudan

${ }^{3}$ Registrar, Obstetric Department, The National Ribat University Hospital, PO box 55, Burri, Khartoum, Sudan

${ }^{4}$ Senior Consultant, Obstetric department, The National Ribat University Hospital, PO box 55, Burri, Khartoum, Sudan

${ }^{5}$ Medical Officer, Obstetric department, The National Ribat University Hospital, PO box 55, Burri, Khartoum, Sudan

${ }^{6}$ Laboratory Department, The National Ribat University Hospital, PO box 55, Burri, Khartoum, Sudan

\begin{abstract}
Objectives: The aim of the study was to know the sero-plevalence of Herpes Simplex Virus (HSV) infection in pregnant women attending a university hospital in Sudan.

Methods: All pregnant women who came for delivery by lower segment caesarean section (LSCS) in National ribat teaching hospital between May and November 2011 were enrolled in this study. Their blood was tested for HSV IgG \& IgM immunoglobulin. Their vulvas were examined for eruptions and ulcers and when those were found surface swabs were taken for isolation of organisms including syphilis. Their blood was also tested for HIV and syphilis.

Results: One hundred thirty pregnant women were included in the study and forty five women (34.6\%) tested positive for the IgG of Herpes virus but none of them was positive for the IgM test.

Fourteen women had genital rashes/ulcers and nine of them tested positive for IgG but not IgM. Eleven women had lip ulcers or blisters and five of them tested positive for herpes.

Conclusion: Acute infection during pregnancy was not documented in this study population and probably women develop immunity to herpes virus early in their reproductive life. Genital rashes and ulcers were not associated with active herpes infection.
\end{abstract}

\section{Keywords: HSV-1; HSV-2; Congenital syphilis; IgG; IgM; LSCS}

\section{Case Report}

Genital herpes infection is the primary cause of genital ulcer disease (GUD) worldwide [1]. The recurrent type is mainly caused by herpes virus simplex type 2 (HSV-2) but can also be caused by HSV-1 which has been estimated to cause about $50 \%$ of cases of primary ano-genital herpes in young adults [2].

European cross-sectional surveys conducted between 1989 and 2000 found that age-standardised HSV-2 seroprevalence ranged from 4\% in England and Wales to 24\% in Bulgaria [3] compared with developing countries, substantially higher rates of HSV-2 have been observed in sub-Saharan Africa ranging from 30\% to $80 \%$ in women and $10 \%$ to $50 \%$ in men $[4,5]$. Few countries have population-based national estimates of HSV-2 that allow the estimation of seroprevalence trends [6]. Sudanese data on this subject is scarce but there was a report linking HSV infection to male sub fertility $[7,8]$.

Congenital HSV infection is rare $[9,10]$ but is higher than that of congenital syphilis, toxoplasmosis, and congenital rubella in years in which the virus was not epidemic. It shares clinical features such as microcephaly, hydrocephalus, and chorioretinitis with other congenital infections and is usually manifested by clinical abnormalities at birth. Postnatal acquisition of HSV is almost always due to HSV-1 and is associated with contact with hospital personnel or family members who are shedding HSV-1 [11].

Most neonatal infections result from exposure to HSV during delivery although in utero and postnatal infections occasionally occur [12]. Infection can be asymptomatic or symptomatic and divided into two categories: infection manifested in the skin, eyes, and mucosa, or CNS-associated infections. The latter are associated with lethargy, poor feeding, and seizure [13].
The risk of transmission is significantly higher among women who acquire genital infection with HSV-1 or HSV-2 during pregnancy than among women with long-standing HSV-2 infection in whom the virus is reactivated in the genital tract at term (25 to $50 \%$ vs. $<1 \%$ ) $[14,15]$. The risk is even more (50 to $80 \%$ ) if women acquire the disease near term $[14,15]$. Most cases of genital HSV infection in women occur without signs or symptoms of disease and are associated with cervical viral shedding [14].

We aimed at studying the sero-prevalence of herpes infection in Sudanese pregnant women attending

National Ribat University Hospital.

\section{Materials and Methods}

\section{Subjects}

All pregnant women who came to deliver by LSCS in National Ribat teaching hospital between May and December 2011 were

*Corresponding author: Eisa Osman El-Amin, Senior consultant, Department of Paediatrics, The National Ribat University hospital, PO box 55, Burri, Khartoum, Sudan, Tel/Fax: 00249 263568; E-mail: eisaelamin@gmail.com

Received July 29, 2013; Accepted August 26, 2013; Published September 01 2013

Citation: El-Amin EO, Elamin OE, Ahmed RAM, Abdulla AK, Elamin SE, et al. (2013) Sero-Prevalence of Herpes Virus Infection in Sudanese Pregnant Women Trop Med Surg 1: 138. doi:10.4172/2329-9088.1000138

Copyright: (c) 2013 El-Amin EO, et al. This is an open-access article distributed under the terms of the Creative Commons Attribution License, which permits unrestricted use, distribution, and reproduction in any medium, provided the original author and source are credited. 
enrolled in this study. It was a convenient sample that allowed time for investigations since many of the normal deliveries, as expected took 24 hour discharge. They were a consecutive case series. Some of them came in labour and the remainder were admitted one day prior to elective caesarean section. After signing a written consent for the research a questionnaire was filled for them detailing their bio-data and the required investigations. The results of investigations were to be available for them and they were promised treatment of the medical problems that might arise.

\section{Laboratory study}

Five $5 \mathrm{ml}$ of blood were taken for complete blood count and herpes IgG and IgM antibodies. We used Anti-HSV-1/2 pool ELIZA (IgG \& IgM) from EUROIMMUN laboratories, Germany with $100 \%$ specificity and sensitivity for IgG tests. The IgM specificity and sensitivity is 93.15 \%and 95.7\% respectively. These kits do not differentiate between HSV1 and HSV-2. Antigen detection was not available for us because of its cost (\$250/90 tests).

We looked for genital blisters and ulcers and took swabs from vagina and introituses for bacterial culture. Other investigations like urine microscopy/culture, blood culture and blood film for malaria were taken as required. All those women with genital lesions were tested for syphilis and HIV after explaining the need for the tests.

\section{Expected outcomes}

The primary expected outcome was the sero-prevalence of HSV infection in pregnant women. Secondary outcome was genital ulcers/ blisters versus maternal sero-pevalence for HSV.

\section{Exclusion criteria}

Women who did not consent for the study and those who left hospital before completion of the study were excluded.

\section{Ethical Considerations}

All participants in the study had to sign consent for participation and the results of investigations were to be conveyed to their treating doctors who will discuss results with them and provide the necessary treatment for free. Those who would test positive for HSV '(IgM positive) were to be offered a test for HIV and syphilis. They were to be treated with Acyclovir [16,17]. Their newborns were to be examined clinically and investigated for herpes infection. Affected babies were to be treated with I.V. acyclovir [18]

\section{Analysis of Results}

Data were collected by two doctors and entered on daily basis to a soft ware using EPI-6 info [19] which is also used for analysis of results. Fischer exact test was used to compare different frequencies [20].

\section{Disclosures}

This study was partly supported by a grant from The National Ribat University to cover the cost of laboratory investigations and there is no conflict of interest to be disclosed. Two collaborates were son and the daughter of the main investigator but they were working in different departments.

\section{Results}

Three hundred and fifty six women delivered in the period of the study and 152 of them (49\%) were by Lower Segment Caesarean Section (LSCS). Out of the 152 women seventeen did not consent and the data of five were incomplete. Non consent was made by ten women against taking extra blood for investigation and seven just did not want to be included. The incomplete data was due to early self discharge from hospital which did not allow time to complete investigations. Therefore one hundred thirty pregnant women were included in the study and 15 of them (11.5\%) were below 20 years of age while 9 of them (7\%) were $>35$ years old (Table 1 ). Parity is shown in Table 2 . Prematurity occurred in 15 women (12\%) and 4 women were postdate.

Thirty women had fever in the week before delivery and in 4 of them it was associated with nonspecific skin rash and two had superficial ulcerations of vulva. No organism was grown from the skin or vulva and they tested negative for syphilis and HIV. Fever was due to urinary tract infection in 6 women, malaria in four and in the remainder fever was thought to be due to nonspecific viral respiratory illnesses. E. coli was the cause of UTI in four out of the six cases and the remainder did not grow organisms.

Those who had superficial dermal breaks without fever were fourteen. Ten of them had lesions in vulvas and seven tested positive for IgG but not for IgM. Skin and lip lesions were seen in seven patients and four of them coincided with genital lesions.

The mean haemoglobin for the study group was $11.6 \mathrm{~g} / \mathrm{dl}$ and only five women had haemoglobin of $<10 \mathrm{~g} / \mathrm{dL}$. The mean WBC count was $8.1 \times 10^{9} / \mathrm{L}$ and the mean lymphocyte count was $2.7 \times 10^{9} / \mathrm{L}$. The mean platelets count was $235 \times 10^{9} / \mathrm{L}$ and six women had platelets lower than $150 \times 10^{9} / \mathrm{L}$ but not less than $110 \times 109 / / \mathrm{L}$.

Forty five women (34.6\%) tested positive for the IgG of Herpes virus (Table 2) but none of them was positive for the IgM test. Table 1 relates sero-positivity to maternal age and Table 2 to parity.

Newborns whose mothers tested positive for HSV were examined for clinical features of intra-uterine infections [10] and none of them had those features. Two other babies had microcephaly without skin or visceral enlargement. Both tested negative for Herpes infection. One of them had familial microcephaly and the other one had trisomy 21.

\section{Discussion}

Forty five women tested positive for herpes IgG which indicates immunity and the negative test for IgM makes active disease unlikely. Commercially available assays to detect antibodies to HSV-2-specific glycoprotein IgG-2 have markedly improved serological diagnosis of HSV-2 infection over the past 10 years [2]. These kits were used in the study, and their sensitivity against western blot ranged from $93 \%$ to $100 \%$, and the specificity ranged from $95 \%$ to $100 \%$ [21].

\begin{tabular}{|l|l|l|l|l|}
\hline $\begin{array}{l}\text { Mother age } \\
\text { (Years) }\end{array}$ & $\begin{array}{l}\text { IgG } \\
\text { Negative }\end{array}$ & $\begin{array}{l}\text { IgG } \\
\text { Positive }\end{array}$ & TOTAL & P value \\
\hline $16-25$ & 34 & 25 & 59 & 0.3320 \\
\hline $26-35$ & 44 & 19 & 63 & 0.6255 \\
\hline$>35$ & 7 & 1 & 8 & 0.2688 \\
\hline TOTAL & 85 & 45 & 130 & \\
\hline
\end{tabular}

Table 1: Sero-prevalence of Herpes infection in relation to maternal age.

\begin{tabular}{|l|l|l|l|l|}
\hline Parity & $\begin{array}{l}\text { IgG } \\
\text { negative }\end{array}$ & $\begin{array}{l}\text { IgG } \\
\text { Positive }\end{array}$ & Total & P value \\
\hline Nulliparous & 5 & 6 & 11 & 0.2052 \\
\hline Multiparous & 66 & 38 & 104 & 0.7845 \\
\hline Grandmultiparous & 14 & 1 & 15 & 0.0373 \\
\hline Total & 85 & 45 & 130 & \\
\hline
\end{tabular}

Table 2: Sero-prevalence of Herpes infection in relation to parity. 
Results in this study denote that immunity to Herpes develops early in life. We could not state with certainty when but probably in childhood because children in the tropics generally meet with many viral illnesses in the environment [2]. This is similar to regional data of HSV infection in children which revealed that $>77 \%$ of Egyptian children below 10 years of age are infected [22]; and $>55 \%$ of Algerian children are also infected [23].

There was no difference in sero-prevalence between women in early reproductive age and late age $(\mathrm{P}=0.3320)$. These findings agree with sub-Saharan work on this subject [24] but do not concur with some European research [25]. The age factor should be considered in the context of population location and behaviour. Most of women 1525 years of age in our study were at risk of HSV early in childhood from the environment while a similar age group in Uganda or Tanzania are at increased risk because of increased sexual activity as has been reported [26-28]. Immunity to HSV seemed to wane as women in our study grew older. Similar observations were made by others who postulated that older cohorts are less widely prone to infection with HSV-2 or that HSV-2 antibody levels may decline in older ages [29]. The risk of male partners harbouring HSV-2 to pregnant women is proven [30] but our data did not show significant difference between those who had more pregnancies as judged by parity (Table 2). In fact grandmultiparity was associated with less seroprevalence ( $p$ 0.0373) but the total number is not great.

Thirty women in the study had fever during the last week of pregnancy. Six of them had skin rashes or genital eruptions and those were highly suspicious for an active HVS infection but they proved not true on IgM testing. Never the less, the lesions were treated with local acyclovir for relief of symptoms and to help reducing shedding of the virus $[2,14]$. We did not look for other viruses but it is a strong possibility because similar studies in the region indicated that $[6,12]$. Ten were proven malaria and UTI which are common in our community. Still we could not determine the cause of fever in the remainder 14 patients although they looked like simple upper respiratory tract infections.

Genital rashes and ulcers were not due to herpes infection in our study population which accords with other regional observations $[31,32]$. Lip lesions indicate immunity to herpes and local activation occurs due to fever or stress as has been reported repeatedly $[6,32]$.

Neonatal Herpes infection was not documented in this study and this is partly due to the small number of candidates in the study but generally the yield of such cases is extremely low [33-35].

\section{Conclusion}

This study revealed that many pregnant women developed immunity to herpes virus early in their reproductive life and acute infection during pregnancy was not documented in this study population. We did not document a real risk for newborns. Genital rashes or ulcers were not associated with active herpes infection. A large scale sero-prevalence survey for HSV and other viruses is needed to draw solid conclusions.

\section{Acknowledgement}

We are very thankful to Ribat National University for the financial support of this study and for their permission to publish its results in this journal. We are grateful to our colleagues in the obstetrics and neonatal departments who allowed us to use data for their patients.

\section{References}

1. World Health Organization. Herpes simplex virus type 2 programmatic and research priorities in developing countries, WHO/HIV AIDS/2001.05. Report of a WHO/UNAIDS/LSHTM Workshop, London. 14-16 February 2001,

2. Centre for Disease Control and Prevention, Atlanta, USA. Sexually ransmitted Diseases Treatment Guidelines 2010:20-21.

3. Pebody RG, Andrews N, Brown D, Gopal R, De Melker H, et al. (2004) The seroepidemiology of herpes simplex virus type 1 and 2 in Europe. Sex Transm Infect 80: 185-191.

4. Fleming DT, McQuillan GM, Johnson RE, Nahmias AJ, Aral SO, et al. (1997) Herpes simplex virus type 2 in the United States, 1976 to 1994. N Engl J Med 337: 1105-1111.

5. Looker KJ, Garnett GP, Schmid GP (2008) An estimate of the global prevalence and incidence of herpes simplex virus type 2 infection. Bull World Health Organ 86: 805-812, A.

6. Ndinya-Achola JO, Kihara AN, Fisher LD, Krone MR, Plummer FA, et al. (1996) Presumptive specific clinical diagnosis of genital ulcer disease (GUD) in a primary health care setting in Nairobi. Int J STD AIDS 7: 201-205.

7. Mihret W, Rinke de Wit TF, Petros B, Mekonnen Y, Tsegaye A, et al. (2002) Herpes simplex virus type 2 seropositivity among urban adults in Africa: results from two cross-sectional surveys in Addis Ababa, Ethiopia. Sex Transm Dis 29: $175-181$

8. Nazar MA (2011) Sudanese male fertility and infections. Sci Parasitol 12(3): 123-129.

9. Morris SR, Bauer HM, Samuel MC, Gallagher D, Bolan G (2008) Neonatal herpes morbidity and mortality in California, 1995-2003. Sex Transm Dis 35: 14-18.

10. Whitley R, Davis EA, Suppapanya N (2007) Incidence of neonatal herpes simplex virus infections in a managed-care population. Sex Transm Dis 34 704-708.

11. Kimberlin DW (2005) Herpes simplex virus infections in neonates and early childhood. Semin Pediatr Infect Dis 16: 271-281.

12. Brown ZA, Selke S, Zeh J, Kopelman J, Maslow A, et al. (1997) The acquisition of herpes simplex virus during pregnancy. N Engl J Med 337: 509-515.

13. Lahat E, Barr J, Barkai G, Paret G, Brand N, et al. (1999) Long term neurological outcome of herpes encephalitis. Arch Dis Child 80: 69-71.

14. Sullender WM, Yasukawa LL, Schwartz M, Pereira L, Hensleigh PA, et al. (1988) Type-specific antibodies to herpes simplex virus type 2 (HSV-2) glycoprotein G in pregnant women, infants exposed to maternal HSV-2 infection at delivery, and infants with neonatal herpes. J Infect Dis 157: 164-171.

15. Herpes simplex. In: Pickering LK, ed. Red Book, 2010: the report of the Committee on Infectious Diseases. Elk Grove Village, IL: American Academy of Pediatrics, 2009: 363-73.

16. Watts DH, Brown ZA, Money D, Selke S, Huang ML, et al. (2003) A doubleblind, randomized, placebo-controlled trial of acyclovir in late pregnancy for the reduction of herpes simplex virus shedding and cesarean delivery. Am J Obstet Gynecol 188: 836-843.

17. Corey L, Wald A, Patel R, Sacks SL, Tyring SK, et al. (2004) Once-daily valacyclovir to reduce the risk of transmission of genital herpes. N Engl J Med 350: $11-20$.

18. Hollier LM, Wendel GD. Third trimester antiviral prophylaxis for preventing maternal genital herpes simplex virus (HSV) recurrences and neonatal infection. Cochrane Database Syst Rev. 2008; 23: CD004946.

19. Swiss Herpes Management Forum (2004) Swiss recommendations for the management of genital herpes and herpes simplex virus infection of the neonate. Swiss Med Wkly 134: 205-214.

20. Geretti AM, Brown DW (2005) National survey of diagnostic services for genital herpes. Sex Transm Infect 81: 316-317.

21. Bennet S, Myatt M, Jolley D, Radalowicsz A (1994) Data Management fo Surveys and Trials. A Practical Primer Using Epi Info. Llanidloes Powsys: Brixton Books; 1994

22. Simon D, Boring JR III. Sensitivity, Specificity, and Predictive Value. In: Clinical Methods: The History, Physical, and Laboratory Examinations.

23. Walker HK, Hall WD, Hurst JW, editors. (3rdedn). 1990; Atlanta: Butterworths; p. $30-2$. 
Citation: El-Amin EO, Elamin OE, Ahmed RAM, Abdulla AK, Elamin SE, et al. (2013) Sero-Prevalence of Herpes Virus Infection in Sudanese Pregnant Women. Trop Med Surg 1: 138. doi:10.4172/2329-9088.1000138

24. Loutfy SA, Alam El-Din HM, Ibrahim MF, Hafez MM (2006) Seroprevalence of herpes simplex virus types 1 and 2, Epstein-Barr virus, and cytomegalovirus in children with acute lymphoblastic leukemia in Egypt. Saudi Med J 27: 11391145 .

25. Meguenni S, Djenaoui T, Bendib A, Bouhadjar H, Lalliam N, et al. (1989) [Herpes simplex virus infections in Algiers]. Arch Inst Pasteur Alger 57: 61-72.

26. Kriebs JM (2008) Understanding herpes simplex virus: transmission, diagnosis, and considerations in pregnancy management. J Midwifery Womens Health 53: $202-208$

27. Cusini M, Ghislanzoni M (2001) The importance of diagnosing genital herpes. J Antimicrob Chemother 47 Suppl T1: 9-16.

28. Kamali A, Nunn AJ, Mulder DW, Van Dyck E, Dobbins JG, et al. (1999) Seroprevalence and incidence of genital ulcer infections in a rural Ugandan population. Sex Transm Infect 75: 98-102.

29. Wagner HU, Van Dyck E, Roggen E, Nunn AJ, Kamali A, et al. (1994) Seroprevalence and incidence of sexually transmitted diseases in a rural Ugandan population. Int J STD AIDS 5: 332-337.
30. Obasi A, Mosha F, Quigley M, Sekirassa Z, Gibbs T, et al. (1999) Antibody to herpes simplex virus type 2 as a marker of sexual risk behavior in rural Tanzania. J Infect Dis 179: 16-24.

31. World Health Organization Herpes simplex virus type 2 programmatic and research priorities in developing countries. WHO/HIV AIDS/2001.05. Report of a WHO/UNAIDS/LSHTM Workshop, 14-16 February 2001, London

32. Thung SF, Grobman WA (2005) The cost-effectiveness of routine antenata screening for maternal herpes simplex virus-1 and -2 antibodies. Am J Obstet Gynecol 192: 483-488.

33. Hoyo C, Hoffman I, Moser BK, Hobbs MM, Kazembe P, et al. (2005) Improving the accuracy of syndromic diagnosis of genital ulcer disease in Malawi. Sex Transm Dis 32: 231-237.

34. Kulhanjian JA, Soroush V, Au DS, Bronzan RN, Yasukawa LL, et al. (1992) Identification of women at unsuspected risk of primary infection with herpes simplex virus type 2 during pregnancy. N Engl J Med 326: 916-920.

35. Kimberlin DW, Lin CY, Jacobs RF, Powell DA, Corey L, et al. (2001) Safety and efficacy of high-dose intravenous acyclovir in the management of neonatal herpes simplex virus infections. Pediatrics 108: 230-238. 